\title{
Article
}

\section{Excavating Occluded Histories at Destrehan Plantation: Afro-Creole Resistance from "Marguerite" to Beyoncé}

Willson, Nicole Louise

Available at http://clok.uclan.ac.uk/30583/

Willson, Nicole Louise ORCID: 0000-0001-5935-9075 (2020) Excavating Occluded Histories at Destrehan Plantation: Afro-Creole Resistance from "Marguerite" to Beyoncé. Journal of American Studies, 54 (4). pp. 775-808. ISSN 0021-8758

It is advisable to refer to the publisher's version if you intend to cite from the work. http://dx.doi.org/10.1017/S0021875819000021

For more information about UCLan's research in this area go to http://www.uclan.ac.uk/researchgroups/ and search for <name of research Group>.

For information about Research generally at UCLan please go to http://www.uclan.ac.uk/research/

All outputs in CLoK are protected by Intellectual Property Rights law, including Copyright law. Copyright, IPR and Moral Rights for the works on this site are retained by the individual authors and/or other copyright owners. Terms and conditions for use of this material are defined in the policies page. 


\section{Excavating Occluded Histories at Destrehan Plantation: Afro-Creole Resistance from 'Margueritte' to Beyoncé}

Destrehan Plantation in St Charles Parish, Louisiana, is a crypt replete with phantoms of the Creole past. Like many of the grand, white houses dotted along the Mississippi River Road, it articulates a narrative of Creole history - a history composed of intersections, collisions, confrontations and exchanges between a myriad of cultures in the colonial Atlantic - that privileges the experiences of elite, white landowners and their legatees. This narrative conspicuously occludes the diverse, metamorphic, and insurgent stories of the Afro-Creole culture that lay at the heart of the plantation infrastructure. Using Destrehan as a point of analytical departure, this article therefore proposes a critical reassessment of plantation sites and their hidden histories in an effort to promote new ways of seeing that foreground Afro-Creole experience and imagine routes to resistance that transcended the historical moment, and continue to resonate in the contemporary African American imaginary. In so doing, it attempts to peel back the multiple layers of occlusion, obfuscation, and erasure embedded within the Creole plantation infrastructure. It examines the narrative of the Creole plantation (as a site and sight of memory) and its various mechanisms of telling, especially through its artefacts, written histories, and docent-led tours, and interrogates the ways in which heritage sites work to contain and circumvent the affective memorialization of Afro-Creole histories through rhetorical strategies of 'erasure and minimization', characterized by plantation scholars Jennifer Eichstedt and Stephen Small as 'symbolic annihilation'. ${ }^{1}$ It therefore upholds Krista Thompson's contention that such sites demand 'a more radical reformulation of the "evidence of things unseen"', and champions the need to 'explor[e] the representational and historical possibilities of absence'. ${ }^{2}$

As a plantation that markets itself as the 'oldest documented plantation home in the lower Mississippi Valley', Destrehan is inscribed with memories of conquest, settlement, labour and industry. ${ }^{3}$ It is also inscribed with complex and contrasting memories of suffering, sorrow, love and community. These memories are invariably bound up with a plantation narrative anchored in

\footnotetext{
${ }^{1}$ Jennifer L. Eichstedt and Stephen Small, Representations of Slavery: Race and Ideology in Southern Plantation Museums (Washington and London: Smithsonian Institution Press, 2002), 105.

${ }^{2}$ Krista Thompson, 'The Evidence of Things Not Photographed: Slavery and Historical Memory in the British West Indies,' Representations, Vol. 113, No. 1 (Winter 2011), 39-71, 63.
} 
the age of slavery and colonialism, but they also extend beyond the life of the slave plantation, and speak to the unarticulated experiences of those who outlived and indeed resisted its repressive infrastructures. Indeed, at its core is a secreted narrative of Afro-Creole insurgency that was borne out in acts of creativity and defiance, and found its ultimate expression in the 1811 German Coast uprising, the largest slave uprising in territorial North America, whose leading agents were tried at Destrehan. ${ }^{4}$ This article therefore seeks to interrogate the legacies of Destrehan's revolutionary history and its various articulations across the heritage site, and examine the wider performative routes of revolution for the Afro-Creole communities that inhabited this space. My use of the term 'Afro-Creole', borrowed from Gwendolyn Midlo Hall, is in this sense significant; it resonates acutely with the transatlantic experience of the enslaved and free Black communities along the Mississippi River Road during the age of slavery and thus challenges the Anglophone biases of American cultural studies that might undermine the complex multicultural lineages of the region. As Midlo Hall notes,

In Louisiana, it is especially important to avoid treating the formation of slave culture in isolation, as if it were sealed off from the rest of society and the world. Culture is a dynamic process. [...] In the Americas, new cultures were formed through intense, and often violent, contacts among people of varied nations, races, classes, languages, and traditions. ${ }^{5}$

The connotations of violence embedded within this term also re-centres the role of cultural rebellion and the way that we think about performative and strategic acts of circumvention and resistance enacted in concert and collaboration. As such, it is helpful in framing a discussion of a multi-modal Black poetics that has an Atlantic diasporic inheritance.

Destrehan also represents an interesting case-study as a heritage site that has, in part, attempted to confront its problematic history and rehabilitate untold narratives of its Creole founding. Its permanent exhibit of artworks that commemorate the 1811 uprising by the folk artist Lorraine Gendron, whose work forms a crucial, if not focal, node for examining such

\footnotetext{
3 'Homepage,' Destrehan Plantation, accessed February 3, 2017, http://www.destrehanplantation.org/. ${ }^{4}$ Ibid.

${ }^{5}$ Gwendolyn Midlo Hall, Africans in Colonial Louisiana: The Development of Afro-Creole Culture in the Eighteenth Century (Baton Rouge: Louisiana State University Press, 1992), xiii.
} 
possibilities within the scope of the tour experience at Destrehan, represents a case in point. This article interrogates such acts of commemorative rehabilitation, probing their inconsistencies and disjunctures, and, in the process, espouses the practice of what Derek Alderman and Rachel Campbell call 'symbolic excavation', positing the need for both creative interdisciplinarity and insurgent acts of narrative reclamation in rehabilitating Afro-Creole histories. ${ }^{6}$ It also seeks to demonstrate the importance of artistic practice in affective memorialization; as Memory Studies scholar Karen E. Till acknowledges, such practices 'challenge dominant regimes of memory by creating spaces that revisit historical social relations and imagine new possibilities. ${ }^{7}$

In its attempt to promote a radical model of (re)reading that takes us closer to the lived possibilities of Destrehan's Afro-Creole forebears, it thus posits the need to adapt creative interdisciplinary solutions that engage communities of colour in a process of affective memorialization. In addition to the works of Gendron, it also examines the interventions made by Beyoncé Knowles Carter's 2016 visual album Lemonade. In Lemonade, Knowles Carter takes her audience on a multi-sensory journey that offers new ways of articulating plantation landscapes, enslaved histories and their legacies through a range of performative media, including poetry, song, dance, oral storytelling, dress, and moving image. In this way, this article suggests, Knowles Carter explodes the narrative possibilities of Afro-Creole histories — an effort which is compounded by a conscientious creative effort to re-envision and remodel the various plantation landscapes along the Louisiana River Road. ${ }^{8}$ In Lemonade, Destrehan figures as a centripetal device that pays homage to Knowles Carter's own Afro-Creole heritage, especially in the penultimate 'Freedom'/'Hope' sequence. By revisiting this contested site-especially within the context of a visual album which explores the performative possibilities of people of colour alongside a series of radical themes - Knowles Carter realigns the focus of the existing

\footnotetext{
${ }^{6}$ See Derek H. Alderman and Rachel M. Campbell, 'Symbolic Excavation and the Artifact Politics of Remembering Slavery in the American South Observations from Walterboro, South Carolina,' Southeastern Geographer, Vol. 48, No. 3 (2008), 338-355, 340.

${ }^{7}$ Karen E. Till, 'Artistic and activist memory-work: Approaching place-based practice,' Memory Studies, Vol. 1, No. 1 (2008), 99-113, 104.

${ }^{8}$ Lauren Laborde, 'Mapping the Louisiana Locations in Beyonce's "Lemonade"', Curbed: New Orleans, last modified June 3, 2016, http://nola.curbed.com/maps/beyonce-lemonade-louisiana-filming-locations.
} 
plantation narrative, and engages in a symbolic act of memory-work, thereby teasing out the Afro-Creole roots and routes of history and memory. ${ }^{9}$

\section{Deconstructing Destrehan: Sites of Silence and Afro-Creole Countercultures}

The Mississippi River Road in Louisiana presents scholars of the Creole Americas with a rich historical topography. The remains of the plantation infrastructure that once upheld the economies of its regional settlers preserve the spectral memory of American creolization. That is to say that these plantation sites bear the memory-traces of the divergent peoples and cultures forced into confrontation in the Atlantic World during the age of slavery. Prior to the Louisiana Purchase of 1803, the plantation economy of territorial Louisiana had centred largely on the production of foodstuffs for more commercially viable plantation economies, such as the French colony of Saint-Domingue. ${ }^{10}$ Up until 1791, when a series of slave insurrections in the northern plantation territories exploded into revolution, Saint-Domingue had been the leading supplier of the world's sugar. ${ }^{11}$ As its colonial economy was riven apart by rebel forces, Louisiana began to occupy a more prominent position in the nexus of Atlantic production and exchange. Land was settled and cultivated, and the diasporic spread of peoples and cultures across the region led to the formation of a uniquely 'southern' plantation culture that is often characterized by depredation, brutality, and exploitation. The plantation economy that took root in Louisiana after the Purchase exacerbated the dependency on African and Afro-Creole labour, extending on the existing colonial complex and Atlantic World markets.

In 1787 Robert Antoine Robin de Logny, commandant of the Second German Coast, entered into a contract with Charles Paquet, a free man of colour and master builder of purported Saint-Domingan origin, to undertake construction of the plantation estate that now stands at Destrehan. Under Robin de Logny’s administration, the plantation farmed indigo — a popular

\footnotetext{
${ }^{9}$ Paul Gilroy, The Black Atlantic: Modernity and Double Consciousness (London and New York: Verso, 1993$), 19$. Gilroy suggests that, in addition to thinking about the relationships between 'roots and rootedness' and identity in modern black culture, we should also consider 'identity as a process of movement and mediation that is more appropriately approached via the homonym routes.' This idea is central to any theorization of Creole life in the Americas.

${ }^{10}$ Cécile Vidal, 'Louisiana in Atlantic Perspective,' in Louisiana: Crossroads of the Atlantic World, ed. Cécile Vidal (Philadelphia: University of Pennsylvania Press, 2014), 10.
} 
commercial crop among the Creole community in Louisiana and indeed elsewhere in the colonial Americas. In 1792, however, Robin de Logny died, and the plantation estate passed to his daughter Marie Claude Céleste Léonore and her husband, Jean Noël D’Estréhan. ${ }^{12}$ The current name of the heritage site therefore encrypts the secret history of its Creole origins and its free Black conception, and anchors it historically within a specified timeframe connected with a particular Creole lineage: that of the Louisiana D'Estréhans. The pre-eminence accorded to the D'Estréhans within this heritage narrative is significant. John Noël was the youngest son of JeanBaptiste D'Estréhan des Tours, who served for many years as Royal Treasurer during the French colonial administration. ${ }^{13}$ Upon the death of Jean-Baptiste in 1765, Jean Noël (who was then only fourteen), became the ward of his elder sister, Jeanne Marguerite, and her husband, Étienne de Boré. De Boré would later become the first mayor of New Orleans, but he made his fortune earlier in life as 'the father to all such as handle the sugar kettle' as he is characterized in George Washington Cable's The Grandissimes. ${ }^{14}$ De Boré had commercialized a process used in colonial Saint-Domingue for the refinement and granulation of sugar. It was owing to his connections across the diasporic, continually creolizing world of the Gulf South that Louisiana became such a viable location for the future cultivation and production of sugar, thus giving rise to an increasingly brutal and labour-intensive slave economy. ${ }^{15}$ From adolescence, Jean Noël received instruction from his brother-in-law on the operation and management of a plantation estate, and it is no surprise that when he and his wife took over the administration of the plantation from Robin de Logny in 1792, he replaced the existing indigo crop with sugar cane. ${ }^{16}$ Conceptually, 'Destrehan' was thus very much central to the foundation of the Creole plantation economy in Louisiana during this transitional period, and these multiple layers of Creole history are buried within the ideological framework of its nomenclature.

\footnotetext{
${ }^{11}$ Doris L. Garraway, The Libertine Colony: Creolization in the Early French Caribbean (Durham: Duke University Press, 2005), 8.

12 'Our History,' Destrehan Plantation, accessed February 9, 2017, http://www.destrehanplantation.org/history.html and 'The Building of a Plantation,' Destrehan Plantation, http://www.destrehanplantation.org/the-building-of-aplantation.html.

${ }^{13}$ Stanley Clisby Arthur, Old Families of Louisiana (Baltimore: Clearfield, 1931), 414.

${ }^{14}$ George Washington Cable, The Grandissimes: A Story of Creole Life (1957; repr. New York: Hill and Wang, 1967), 80.

15 Jane Lucas De Grummond, Renato Beluche: Smuggler, Privateer, and Patriot, 1780-1860 (Baton Rouge and London: Louisiana State University Press, 1983), 29-30. De Boré employed Antoine Morin, a refugee from SaintDomingue, to build a sugar works on his failing indigo plantation. Morin developed the process of sugar granulation which enabled De Boré to transform it into a successful export commodity.

16 'The Building of a Plantation.'
} 
These layers are physically articulated in the architectural formation of the 'big house' that visitors approach as they turn off the River Road into the plantation complex at Destrehan. Indeed, the existing edifice harbours the skeletal remains of the original Creole raised cottage built between 1787 and 1790, which saw significant cosmetic overhaul in 1840, when it was remodelled in the neoclassical taste and the slim, West Indian balusters flanking the gallery were replaced by double-height doric columns to create a portico across the front of the house (see Figures 1 and 2). Despite these innovations, and in contrast to other Creole plantations in the region, the overall Creole structure of the house built and designed by the free-coloured Charles Paquet was altered very marginally. Furthermore, while these aesthetic transformations attempted to invoke the classical values bound up with notions of the civic patrie, the structure was paradoxically made to service the needs of the same exploitative plantation economy that had serviced Creole Louisiana since its colonial inception.

As Destrehan's tour guides attempt to demonstrate, its Afro-Creole foundations remain fundamentally integral to its existing legacy as a heritage site. As we are guided through the 'big house' we are led into a room at the top of the stairs which showcases the masonry techniques of the enslaved labourers who were employed in its construction. Here, a large section of the inner wall has been exposed to reveal a form of mortar known in Creole parlance as bousillage entre poteaux. Bousillage, we are told, was a technique deployed in housebuilding in Creole Louisiana using mud to fill the gaps between wooden struts. The fingerprints of the enslaved masons who left their marks in the bousillage remain a living testimony to Afro-Creole exchanges that were central to the construction and operation of the plantation complex (Figure 3). These indelible marks of forced labour have been exposed for us to see. However, as Modlin, Alderman and Gentry note, while the plantation tour 'acknowledg[es ...] enslaved labor' and its centrality to the life of Destrehan, guides do not offer 'the kind of engaged discussion that would help [visitors] identify with that labor in affective ways'. ${ }^{17}$ Within the plantation narrative, and within the plantation space, Afro-Creole lives serve a functional and utilitarian purpose, and can be neatly consolidated within proscribed spaces demarcated by the tour guide. This

\footnotetext{
${ }^{17}$ E. Arnold Modlin Jr, Derek H. Alderman and Glenn W. Gentry, 'Tour Guides as Creators of Empathy: The Role of Affective Inequality in Marginalizing the Enslaved at Plantation House Museums,' Tourist Studies, Vol. 11, No. 1 (2011), 3-19., 13.
} 
compartmentalization of individual histories obscures the way in which the Creole plantation operated as a hegemonic institution, and negates the vital connections between the 'big house', labour, capital, abuse and trauma. As Eichstedt and Small posit, Destrehan falls into the category of plantation houses that engage in 'relative incorporation': although it incorporates slavery into its docent-led narrative, it 'neither clarifies the economic importance of slavery nor complicates the reading of the white enslavers, but instead leaves intact their construction as hardworking, ingenious, and generally noble.' 18 Such acts of 'showing' thus serve in part to reinforce the systematic anonymization of enslaved people in the Creole Americas. In this sense, the finger holes within the bousillage signify the inherited trauma of untold and incomplete stories of slave life suppressed and subsumed by the plantation complex. Their very existence nevertheless affirms their ability to elude their total erasure.

Admittedly, Destrehan attempts to resolve this problem of disconnection through its rigorous demonstration schedule, which allows visitors to gain palpable insights into the working life of the plantation. This includes a demonstration on the making of bousillage. However, these demonstrations feature only as an optional part of the tour experience. There is no connective dialogue, in this sense, between artefact and lived experience, making it difficult for visitors to engage in what Alderman and Campbell refer to as the important 'memory work' necessary to truly rehabilitate the spectral histories of the Afro-Creole labourers who were so foundational to this process. ${ }^{19}$ Moreover, while such a demonstration might serve to offer insights into the lives of the anonymous, the tone is inadequate to the task of fully capturing the brutal reality of plantation labour and the difficulties encountered in attempting to forge a life beyond it. The time allocated for the demonstration, for example, is demarcated by the presence of an audience, and strictly confined to Destrehan's hours of operation, which provides us with no real sense of the intense surveillance to which enslaved workers were subjected, nor does it accurately reflect the longevity of the working day, which, for a slave, typically extended from dawn until late afternoon. While the Louisiana Code Noir, established in 1724 by the French colonial administration and thereafter adopted by the Spanish (and, to some extent, adapted by the United

\footnotetext{
${ }^{18}$ Eichstedt and Small, 203; 210.

${ }^{19}$ Adams and Campbell, 340.
} 
States), made provisions for a 'rest' day within the working week, there were strict proscriptions on how this time could be spent. Article XIII, for example, pronounced:

We forbid slaves belonging to different masters to gather in crowds either by day or night, under the pretext of a wedding, or for any other cause, either at the dwelling or on the grounds of one of their masters, or elsewhere, and much less on the highways or in secluded places, under the penalty of corporal punishment, which shall not be less than the whip. In case of frequent offences of the kind, the offenders shall be branded with the mark of the flower de luce, and should there be aggravating circumstances, capital punishment may be applied, at the discretion of our judges. ${ }^{20}$

Such legislative proscriptions articulate the repressive architecture of the Creole plantation system. These proscriptions, like the fingerprints in the bousillage, nevertheless serve to illustrate colonial anxieties about the rebellious countercultures forged within Afro-Creole communities. These communities bore the unprecedented burden of ruthless plantation labour, but actively resisted this burden through acts of cultural defiance - through the forging of relationships, the practice of communal worship and congregation, and through performance. Diverse cultural groups came together to forge new syncretic social customs that facilitated the preservation of African cultures and created autonomous spaces within the repressive institution of the plantation. As Midlo Hall notes, 'the cultural materials brought [to Louisiana] by Africans often turned out to be the most adaptive.' 21

Nevertheless, neither the brutality of enslaved labour, nor the countercultural defiance of Afro-Creole labourers who sought to undermine this oppressive regime features as a part of this demonstrative experience. Rather, the whimsical narrative of the demonstrator, dressed in 'authentic' Creole costume, presents a romantic view of southern folklife. The resulting effect is one of 'moonlight and magnolia' escapism rather than uncompromising verisimilitude. ${ }^{22}$ Such performative gestures decentralize discussions about Afro-Creole life on the plantation. Essentially, then, although these demonstrative and performative gestures are intended to

20 'A Translation of the Black Code of Louisiana,' in Historical Collections of Louisiana, Embracing Translations of Many Rare and Valuable Documents Relating to the Natural, Civil and Political History of that State, ed. B. F. French, 5 Vols, Vol. 3 (D. Appleton \& Co., 1851), 89-100, 90.

${ }^{21}$ Midlo Hall, Africans in Colonial Louisiana, 2. 
recreate an 'authentic' historical experience, they are distinctly disembodied from their historical reality. In this sense, the views of Tara McPherson, writing nearly fifteen years ago on the 'nostalgia industry' of the 'imagined South', still hold true - that the 'contemporary plantation tour functions as a displacement, reflecting dominant culture's inability to imagine the traumas of slavery in a manner that connects slavery to its historic locale and context' ${ }^{23}$ That context of Creole connections, confrontations, and crossings is deconstructed and disconnected, and each component part is confined to its own de-contextualized space.

This sense of nostalgic disconnect is reinforced by the fact that the house and grounds are preserved in historical stasis, during the period of colonial and antebellum slavery, and during the reign of the Creole D'Estréhans in particular. Indeed, although we learn at one point on the tour that the plantation served as a Home Colony run by the Freedmen's Bureau after the end of the Civil War, the restoration of the estate negates its radical historical (and indeed revolutionary) metamorphoses. This invalidates both its Afro-Creole roots and routes, which expose a long history of transformation and overhaul wrought through struggle against a dominant white plantation infrastructure. Although as Horton notes, it is necessary for plantation sites to engage in 'meaningful conversations about race [...] within the context of history, ${ }^{24}$ it is also necessary to acknowledge that history is neither static, frozen, nor linear. As Eichstedt and Small argue, this mode of telling 'decontextualizes people and practices, removing them from concrete historical moments, dynamics, and politics. ${ }^{25}$ To anchor the plantation within a singular historical moment that negates its historical afterlife as a Home Colony does not confront how the Afro-Creole inhabitants that were so central to its operation attempted to deconstruct and rewrite this history at successive moments throughout its life-cycle — most notably, and most radically, during the 1811 German Coast Uprising.

That the historical experience of the plantation tour focuses predominantly on the legacies of the elite white householders of the 'big house' should really come as no surprise

\footnotetext{
22 James Oliver Horton, 'Presenting Slavery: The Perils of Telling America's Racial Story,' The Public Historian, Vol. 21, No. 4 (1999), 19-38, 24.

${ }^{23}$ Tara McPherson, Reconstructing Dixie: Race, Gender, and Nostalgia in the Imagined South (Durham and London: Duke University Press, 2003), 45.

${ }^{24}$ Horton, 36.

${ }^{25}$ Eichstedt and Small, 138.
} 
when the histories of the enslaved at such sites are so often reduced to inventorial records of plantation 'stock'. In this sense, it is important to recognize that Destrehan attempts to rehabilitate some of the Afro-Creole personalities that the plantation archive actively disavows. The tour engages its visitors to speculate, for example, on the various lives of the free-coloured mason, Charles Paquet, and the free-coloured artisan Dutreuil Barjon, whose furniture remains a prominent feature within the 'big house'. Barjon, as the tour aptly affirms, was a native and former resident of the Saint-Domingan town of Jérémie who arrived in New Orleans during the upheaval of the revolutionary diaspora. ${ }^{26}$ His furniture's presence within the house is thus a clear reflection on the legacies left by Saint-Domingan migrants from both sides of the racial divide on the wider Creole culture of New Orleans in the late eighteenth and early nineteenth centuries. It is also a reflection on the creative agency and the routes to self-making available to free persons of colour within Creole slaveholding society.

In addition to its narrative accounts of the legacies of Paquet and Barjon, the tour also offers partial insights into the lives of less indelible and more inconspicuous personalities. In the dining area preserved for children and slaves, visitors encounter a life-size waxwork mannequin of 'Margueritte', modelled on an enslaved woman who lived on the the plantation, born in Louisiana in 1740. At Destrehan, she served as a cook and laundress - a fact that is articulated visually in the accoutrements of labour that adorn her (Figure 4). However, although, as Modlin notes, 'visitors on tour see the mannequin of Margueritte before seeing the mannequin of Jean Noel Destrehan', ${ }^{27}$ the pre-eminence of her narrative is undercut by the lack of affective unity between her symbolic manifestation and her personal history. The scene in which she is presented is one of comfortable, sanitized domesticity. Moreover, while the physical manifestation of Margueritte's mannequin attempts to recuperate a more intimate personal narrative by presenting a figure to which visitors can connect on a physical and sensory level, it also reproduces historic silences. Margueritte is enslaved; she wears the uniform of labour; she can also trace her lineage to Africa, which we can infer, perhaps, from the colourful tignon wrapped about her head. These historical materialities nevertheless jar uncannily with the fact

\footnotetext{
26 'Dutreuil Barjon Furniture', Le Musée de F.P.C., accessed February 20, 2017, http://www.lemuseedefpc.com/footsteps/unique-holdings/.

${ }^{27}$ E. Arnold Modlin Jr, 'Representing Slavery at Plantation-House Museums in the U.S. South: A Dynamic Spatial Process,' Historical Geography, Vol. 39 (2011): 147-173, 165.
} 
that, phenotypically, Margueritte is almost white. Indeed, there is barely any distinction between the skin tone of Margueritte and that of Jean Noël, whose mannequin is housed in the upper parlour. The sense of uncanny dis-ease that we are meant to feel about the encrypted history of Margueritte's maternal ancestors, who were likely subjected to systematic sexual abuse by their white overlords is nevertheless treated with a palpable trepidation. Any possible connection between materiality and trauma is also subverted by the disconnection between slave life on the wider plantation and domestic life in the 'big house'. Given that the institutionalized rape of women of colour was a fundamental engine of the plantation regime, the conscious choice to frame Margueritte's history as one of quaint domestication is decidedly apolitical.

Embedded in the silences about Afro-Creole life on the plantation are thus numerous unrealized possibilities that might serve to bring Margueritte's impersonal and static presence to life, connecting her story with the hundreds of other Afro-Creole histories that represented the very lifeblood of Destrehan. As African American actress, comedian and writer Azie Dungey has acknowledged, such a singular representation of the enslaved experience does not do justice to those whose stories remain untold. In episode 623 of the podcast This American Life, 'We Are in the Future', Dungey recounts her experience of performing as an enslaved person for tour visitors at George Washington's plantation estate Mount Vernon when she had just left college. In this account, she speaks of how she inhabited the persona of an enslaved woman named Caroline Branham. While the experience gave her the opportunity to imagine the possibilities of the unrepresented multitudes, she notes that there were 316 slaves who lived on the Mount Vernon plantation during Caroline's lifetime and attests to the difficulty of striving 'to be all 316 people' at once. ${ }^{28}$ While tour groups at Destrehan are encouraged to explore the grounds of the plantation, and speculate on the manifold possibilities of the enslaved experience as they traverse the 'authentic' slave habitations that once belonged to Helvetia Plantation (destroyed by Hurricane Betsy in 1965), there is a prevailing disconnect between the intimate Creole histories of the 'big house', and their impact on and interactions with those outside. Moreover, the revolutionary and countercultural threat that such communities and cultures represented within

\footnotetext{
28 'We Are in the Future', This American Life, accessed May 14, 2018, https://www.thisamericanlife.org/623/we-
} are-in-the-future. 
the plantation complex is effectively neutralized owing to their consolidation within the synecdochic figure of Margeritte.

\section{Rebellious Countercultures, Artistic Practice and Activist Memory-Work: Destrehan's German Coast Uprising Exhibit}

Although the static figure of Margueritte embodies Destrehan's many imperfections, it would be disingenuous to suggest that its efforts at telling intersectional and affective Creole histories is wholly superficial. Indeed, the permanent exhibit of Hahnsville folk artist Lorraine Gendron's artworks depicting the story of the 1811 slave revolt along the German Coast goes a log way toward fulfilling a 'symbolic excavation' of an alternative and insurgent Afro-Creole experience. Indeed, Gendron's artworks, their configuration within the exhibition space, and the associated dialogue that frames them, form part of a significant 'reconstructive process, the process of moving the enslaved from the realm of being forgotten to the realm of being remembered and recognized publicly. ${ }^{29}$ The exhibit is housed in Destrehan's Education Centre, an overseer's cabin which formerly belonged to the Caire-Graugnard Plantation in Edgard and was donated to Destrehan in 2003 (Figure 5). While admittedly posing certain ideological problems due to its distance from the 'big house', which inhibits visitors from being able to connect with the stories that it helps to recuperate, the chosen exhibition space has a particular symbolic resonance. As a former overseer's cabin, it marks a sight and site of oppression and brutality that marked the daily working life of the Creole plantation. The conscious choice to transform it into an education centre that 'excavates' the story of the 1811 slave revolt thus represents a symbolic inversion that supplants this exploitative narrative with a rebellious counter-narrative that brings to light important and often occluded oppositional Creole histories. In this way, as Modlin notes,

visitors are presented with 'creative ways to look beyond ownership when considering slavery.'30 This is central to providing authentic and nuanced understandings of Afro-Creole life that help to elicit the necessary affective 'memory-work' that might transform the colonialist narrative of the plantation.

\footnotetext{
${ }^{29}$ Alderman and Campbell, 342.

${ }^{30}$ Modlin, 'Representing Slavery', 165.
} 
As Alderman and Campbell note, '[t]he excavation or reconstruction of the history of slavery relies on a direct engagement with the politics of collecting, interpreting, and representing artifacts. ${ }^{31}$ The exhibit adapts multimedia and multidisciplinary techniques that do not rely solely on visual articulation (like the mannequin of Margueritte), but work together to tell a complex, multilayered story that seeks to build understanding through sensory experience. The slave revolt was the largest in North American history, and although exact numbers cannot be clarified with complete certainty, it is estimated that the number of enslaved people involved in the uprising totalled between 150 and $500 .{ }^{32}$ Led by the free man of colour, Charles Deslondes (another native of Saint-Domingue), the insurrection broke out on the plantation of Manuel Andry on the evening of January 8 1811, before spreading throughout St. John the Baptist Parish. Although Andry's son was killed in the affray, Andry himself survived, and notified the authorities. A militia was soon despatched, and the slaves involved were outnumbered in battle. Those that survived the brutal massacre that ensued were rounded up and captured. On January 13, a trial was held on the site of Destrehan Plantation. Twenty-one slaves were found guilty and sentenced to death, and after their execution, their bodies were decapitated and their heads placed on pikes along the River Road to serve as a warning to any unruly slaves in the region. ${ }^{33}$

The framework of this story is established through a series of acrylic paintings on wood that line the walls of the cabin. Each of Gendron's paintings represents a fragment within a sequential narrative, which begins with 'Maroons Meeting' in the Louisiana swamps, where the renegade army, partially concealed by cypress trees, lays the conspiratorial foundations for the events that follow. The next painting in the sequence, captioned 'Revolt', depicts a band of enslaved men armed with makeshift weapons, marching into battle. The following paintings showcase the capture, trial, and execution of the rebel slaves. The paintings bring vividly to life a narrative that is so central to the intersected Creole histories of the region, demonstrating how place and community undergirded rebellious Afro-Creole countercultures. Nowhere is this better articulated than in the painting depicting the marching troupe of rebel slaves against a regional backdrop that includes a raised Creole cottage (painted in the archetypal Creole yellow) flanked

\footnotetext{
31 Alderman and Campbell, 344.

32 Mark Cave, "German Coast Uprising (1811)," in Slavery in the United States: A Social, Political, and Historical Encyclopedia, Vol. 1, ed. Junius P. Rodriguez (Santa Barbara: ABC-CLIO, 2007), 315-316, 315.

33 Ibid.
} 
by two garçonnières (Figure 6). The complexity of this intersectional and localized story is compounded by the central attraction of Gendron's woodcut sculpture (Figure 7). As visitors walk around the sculpture, positioned at the centre of the exhibition space, different vantages give prominence to different personalities. The sculpture thus explodes the unexplored possibilities of the sequential, linear, two-dimensional narrative that frame it. In this way, it promotes a continual return to the site of revolutionary action and distorts the hegemonic framework of imposed historical time. Its integration of natural materials, which include cypress wood and Spanish moss (Figure 8), reinforces its organic physicality and regional specificity. This sensory and cultural routedness is supplemented by the strategic display of real instruments of torture and subordination that were used in the daily operation of the Creole plantation, including such objects as manacles and bayonets (Figure 9), and a series of detailed textual descriptions that pay tribute to the Destrehan slaves that lost their lives in this struggle for freedom.

Unlike other components of the plantation space at Destrehan, the exhibit of the 1811 uprising tells an affective story of Afro-Creole experience that thrusts into the foreground narratives of countercultural resistance. Although Gendron affirms that she did not wish to make her artworks 'too brutal', she succeeds in telling a compelling and evocative story that is crucial to the memory of the Creole landscape, and helps to refocus the gaze of the outside viewer away from the lives of the plantation mistresses and masters, and towards the lesser-known and lesserarticulated stories of Creole life which remain buried beneath them. ${ }^{34}$ In this sense, the Education Centre, and Gendron's artworks in particular, represent a crucial intervention in what Till calls 'artistic and activist place-based memory practice'. That is to say that it 'remains sensitive to the ways individuals and groups understand their pasts and possible futures through the relationships they and others have with place. ${ }^{35}$ However, while this exhibit should form the locus of the plantation tour and the locus of any activist engagement work with the local community, it features only as an optional attraction at the end of the guided tour. As a result, the potency of this exercise in symbolic realignment is muted, and the tour guides miss an important opportunity to create a connective dialogue that offsets the systematic erasure and 'symbolic

\footnotetext{
${ }^{34}$ Lorraine Gendron (personal communication, February 13, 2017)

${ }^{35}$ Till, 102.
} 
annihilation' of Afro-Creole lives. Symbolic excavation must therefore attempt to bridge the gap between a heritage framework that seeks to preserve history, and a creative praxis that stimulates new discussions about that history. As Till notes, 'by taking seriously artistic and activist placebased practice $[\ldots]$ we can $[\ldots]$ begin building responsible research agendas that contribute to more socially just futures. ${ }^{36}$

At the end of the tour, visitors to Destrehan are reminded of the site's prevailing significance within a larger creative culture industry that upholds a particular mythos of Creole life in the American South: the house and grounds have served as a film set for Hollywood blockbusters such as Interview with the Vampire and 12 Years a Slave, for example, which demonstrates its peculiar resonance within divergent narratives of southern horror. More recently, however, it has also served as one of several key plantation backdrops for Beyoncé Knowles Carter's visual album, Lemonade. Unlike other artistic ventures that utilize the plantation space to service a particular geographical and historical mythology, Lemonade expands the conventional parameters (and the parochial white gaze) of the plantation narrative, and explodes the compartmentalization of Afro-Creole histories that traditionally takes place within its parameters. In this creative exercise, Knowles Carter challenges the narratorial imbalance of the Creole plantation and demonstrates how to creatively renegotiate the terrain on which its stories are told. By engaging in her own 'symbolic excavation', she creatively re-envisions the Creole histories of the Louisiana plantation, and offers multidisciplinary solutions for how the plantation might, in turn, reimagine itself in a way that embraces the memories of its local community.

\section{Hope/Freedom: Affective Memorialization and Imagined Possibility in Beyoncé's}

\section{Lemonade}

Knowles Carter's Lemonade celebrates the roots and routes of Afro-Creole experience through a multitude of performative media. Lyrical references to regionally-specific cultural phenomena such as 'hot sauce', 'cornbread', and 'collard greens', and visual allusions to the devastating impact of Hurricane Katrina, to the iconic New Orleans 'Superdome', to African American marching bands, and to the historical tradition of Mardi Gras - and masquerade more

\footnotetext{
${ }^{36}$ Ibid., 109.
} 
generally - serve to anchor the album firmly within a context of Afro-Creole struggle, adaptation, and cultural resilience. Similar references abound throughout the visual album: references to the plantation; to the physical and emotional labour borne by Black women under repressive white (para- and neo-)colonial apparatuses; to the perpetuation of structural inequalities whose roots can be traced to slavery. It presents an uncanny reflection of the dark heart of the region and its history. ${ }^{37}$ Shot almost entirely at Destrehan Plantation, Lemonade's 'Hope'/‘Freedom' sequence presents a gateway into the past that penetrates to the core of such cultural experiences and imagines creative possibilities that articulate rebellious countercultures and redemptive community-oriented futures. It confronts the traumatic memories of the plantation landscape, but also showcases the progressive, affective, and inclusive modes of telling that fortify an insurgent Afro-Creole poetics, which in turn inform our understandings of how such spaces can be better theorized and de-/re-constructed. ${ }^{38}$

The sequence opens onto a full-colour scene depicting a group of women preparing food in the building that previously served as the old kitchen outbuilding on Destrehan Plantation. The scene is one of abundance and uplift, and the costumes worn by each of the women serve to reinforce their kaleidoscopic variety; while their evocation of antebellum Victoriana harkens back to a specific period in the historical past, they also reflect the adaptations, innovations, and re-articulations that became a hallmark of Afro-Creole life during the age of slavery and beyond. As Simmons notes, it articulates a kind of " "present-past time-space" that calls upon enslaved ancestors, just as it points to the future' ${ }^{39}$ In other words, while looking back, it also looks decisively forward, and, in so doing, creates a new life for a space typically defined within the plantation complex as a space of labour and exploitation. In so doing, it celebrates the vitality and strength of Black female communities, and opens our imagination to new possibilities for Destrehan's real Afro-Creole personalities - personalities such as Margueritte, an enslaved

\footnotetext{
${ }^{37}$ LaKisha Michelle Simmons notes that the visual album 'is haunting because of its specificity to place'. LaKisha Michelle Simmons, 'Landscapes, Memories, and Histories in Beyoncé's Lemonade,' UNC Press Blog, last modified April 28, 2016, http://uncpressblog.com/2016/04/28/lakisha-simmons-beyonces-lemonade/.

${ }^{38}$ The multimodal strategies that compose this Afro-Creole poetics are also central to Clyde Woods's notion of a 'blues epistemology'. Although I owe a crucial debt to the pioneering Black Studies scholarship of Clyde Woods, I prefer to use the term 'Afro-Creole poetics' over 'blues epistemology', as the latter inadvertently promotes an Anglophone bias that is not necessarily helpful in negotiating the cultural complexity of the region. See Clyde Woods, 'Sittin' on Top of the World": The Challenges of Blues and Hip Hop Geography,' in Black Geographies and the Politics of Place, ed. Katherine McKittrick and Clyde Woods (Cambridge: South End Press, 2007), 46-81. ${ }^{39}$ Simmons.
} 
woman who no doubt inhabited this space, or a space very much like it—defined within the plantation narrative solely by their labour and their relationship to the white D'Estréhans of the 'big house'.

The scene is supplemented by a non-diegetic voice-over in which Knowles Carter recites lines from a poem written by the Kenya-born British-Somali poet, Warsan Shire, in which she recalls a birthing dream:

That night in a dream, the first girl emerges from a slit in my stomach. The scar heals into a smile. The man I love pulls the stitches out with his fingernails. We leave black sutures curling on the side of the bath.

I wake as the second girl crawls headfirst up my throat, a flower blossoming out of the hole in my face. ${ }^{40}$

The compelling imagery of these lines captures the conflicting sensibilities of pain and healing and their embeddedness within the plantation landscape. While the imagined birthing process is visceral and violent, this is offset by a restorative energy that is espouses renewal. Corporeal metamorphoses transform scars into smiles and children into flowers, emphasizing the resilience of the Black female body in the face of trauma. This dichotomous perspective counterbalances monolithic interpretations of Black female life within the Creole plantation complex, and offers an alternative, nuanced narrative that situates the Afro-Creole family firmly at the intersection of human experience. This narrative reminds us of the complex and multifarious challenges faced by Black women, whose reproductive organs were exploited as a means to sustain the plantation infrastructure - a fact that is compounded by the symbolic visualization of spaces formerly inhabited by enslaved people within this sequence. It also draws into sharp focus, however, the kinds of expressive strategies that were deployed in an attempt to combat the assaults against enslaved families and Afro-Creole kinship networks more broadly.

Indeed, in spite of pernicious attempts made by the plantocracy to circumvent individual autonomy and erase family ties within enslaved communities, enslaved women fought hard to 
preserve kinship networks and inherited ancestral narratives. The bonds between mothers, daughters, and granddaughters that are celebrated in Lemonade were fiercely contested in the age of slavery - a fact recognized by the tenacious efforts of Molly Horniblow, grandmother to Harriet Jacobs, who fought hard to keep her family safe from the encroaching threat of the slaveocracy in South Carolina. ${ }^{41}$ For those unable to read or write, extra-discursive media such as oral storytelling became a dominant device of preservation within these kinship networks.

Knowles Carter's invocation of spoken-word media within this sequence asserts the necessity for reassembling alternative modes of Creole narrativity within the plantation space- both at Destrehan and elsewhere - that acknowledge the ways in which people of colour kept their histories alive, and created new ones in the process. This is especially pertinent when considering the importance of oral narrativity to the region (particularly the trickster tales of Compair Lapin, or Brer Rabbit) and its prominence within broader diasporic Afro-Creole cultures. ${ }^{42}$ The historic importance of these narrative traditions is in part acknowledged in the tours of enslaved spaces at Laura Plantation in Vacherie, where Creole writer Alcée Fortier was said to have recorded a number of Afro-Creole tales, proverbs, and songs, including stories of Brer Rabbit. ${ }^{43}$ By exploring these alternative modes of telling, conventional linear modes that privilege elite white histories and plantation infrastructures (and rely on written media which, for Afro-Creole communities throughout history, may not even exist) are therefore disrupted, and we are forced to look in unconventional places to seek out the often occluded voices which speak to the diasporic routes and intersections of Creole life at all levels. As Clyde Woods notes of the 'blues worldview', the evolution of such exclusively African diasporic modes 'enabled the construction of new communities, institutions and social practices'. Like his 'blues epistemology', an AfroCreole poetics has offered those within the Afro-Creole community a 'constantly evolving language to discuss [...] freedom, dreams, agendas and plans' across multiple generations. ${ }^{44}$ In this way, conventional white, colonialist heritage narratives can be deconstructed through bold acts of Afro-Creole creativity and reinvention.

\footnotetext{
40 Warsan Shire, quoted in Beyoncé Knowles Carter, Lemonade (2016), Tidal 46:26-47:18/1:05:50, accessed March 3, 2017, https://listen.tidal.com/video/59727844.

${ }^{41}$ See Harriet Jacobs, 'Incidents in the Life of a Slave Girl,' in The Classic Slave Naratives, ed. Henry Louis Gates, Jr. (New York: Mentor, 1987).

${ }^{42}$ Willie Lee Nichols Rose ed., A Documentary History of Slavery in North America (Athens and London: The University of Georgia Press, 1999), 251.

${ }^{43}$ Catharine Savage Brosman, Louisiana Creole Literature: A Historical Study (Jackson: University Press of Mississippi, 2013), 119.
} 
These scenes of communal female uplift, which celebrate and foreground Black female voices, form a prologue to Knowles Carter's song 'Freedom' (a song co-written with rap artist Kendrick Lamar). In the scene that follows, a tonal and atmospheric transition occurs, and the camera cross-cuts from the uplifting, full-colour kitchen scene to an outdoor setting shot in black and white. An audience of Black female onlookers assembles before a stage - a set-piece that forms part of the real heritage landscape at Destrehan Plantation — as they await the impending performance. Amid the faces in the audience are those of Sybrina Fulton, Lezley McSpadden, and Gwen Carr, the respective mothers of Trayvon Martin, Michael Brown, and Eric Garnerthree young Black men who were tragically killed in altercations with law enforcement officers during the past decade. By including these mothers in her assemblage of Black women, Knowles Carter not only highlights the unique struggles of Black families denied justice by the law (and champions her political solidarity with the 'Black Lives Matter' movement), but also foregrounds the link between modern law enforcement infrastructures - and, by extension, vigilante violence, the prison-industrial complex, and the pervasive institutional disregard for the value of Black lives - and the exploitative infrastructures of the Creole plantation. ${ }^{45}$ This kind of activist artistic engagement therefore instils the idea that, as Till suggests, 'places [and AfroCreole plantation spaces in particular] are embodied contexts of experience, but also porous and mobile, connected to other places, times and peoples. ${ }^{46}$ The emergent narrative is one that understands Afro-Creole histories as a series of life-cycles that continually return to the point of origin, informed by the legacies of past experience, which stress the importance of understanding, within the plantation complex, how the seemingly distant histories of the slaveholding past inform the present. Given the occlusion of Afro-Creole histories within the heritage narrative at Destrehan, and the site's embeddedness within a particular historical moment, this is a highly political act of re-centring, which encourages witnesses to engage in a 'symbolic excavation' that moves beyond 'history' into the realm of community-focused

\footnotetext{
${ }^{44}$ Woods, 59.

45 Angela Davis, 'Political Prisoners, Prisons and Black Liberation,' in If They Come in the Morning: Voices of Resistance, ed. Angela Y. Davis (1971; repr. 2016): 33-52, 35. Davis notes that 'slavery faded away into a more subtle and yet equally pernicious apparatus to dominate Black people [...] After the Civil War, the Black Codes, successors to the old slave codes, legalized convict labor, prohibited social intercourse between Blacks and whites, gave white employers an excessive degree of control over the private lives of Black workers, and generally codified racism and terror.'

${ }^{46}$ Till, 105.
} 
memory-work; in other words, in addition to contemplating how far we've travelled, we're also asked to confront the damning continuities. Knowles Carter's aesthetic approach thus eschews the solely empathetic responses to the Afro-Creole plantation criticized by Matthew Cook and elicits 'important responses such as solidarity with the descendants of the enslaved community. ${ }^{47}$

This act of re-centring is magnified visually by the fact that Knowles Carter focalizes the gaze of the viewer into the spaces that are typically hidden from view. Indeed, whereas the "big house' is usually the first thing that we see on visiting such heritage sites (Destrehan included), our gaze is directed, in this instance, toward the stage - situated behind the 'big house' on the Destrehan Estate (see Figures 10 and 11). In this sense, our parochial gaze is inverted and the posterior space becomes the anterior space. This visual reconfiguration subverts the conventional plantation narrative which privileges the histories of elite, white slaveowners, and brings the occluded countercultural voices of the Creole plantation to the foreground. As a result, the frame of reference for understanding Afro-Creole histories undergoes a radical metamorphosis; rather than thinking about Afro-Creole histories purely through the prism of slavery and subjection (ergo, through the dominant class of white elites), we are encouraged to situate Creole lives within the multiple possibilities of lived experience: of crossings, collaborations, and reinventions; of creativity, uplift, and indeed rebellion. As Ciji Dodds, Danielle Fuentes Morgan, and Lauren B. Parker acknowledge, Beyoncé reaches into the deepest, darkest depths of Louisiana's Creole history, and 'find[s] the beauty in that history'. ${ }^{48}$ Each history is unique and personal, and the manifold possibilities of Afro-Creole life are articulated in the variety of expressive gestures performed by Knowles Carter and her ensemble of Black women. This visual multiplicity works to excavate the myriad voices of the nondescript and nameless personalities that contributed to the history of Destrehan Plantation during its various life-cycles.

The kaleidoscopic variety of visual imagery is amplified by the sonic arrangement against which the sequence is set. Knowles Carter's stage performance commences as an unaccompanied

\footnotetext{
${ }^{47}$ Matthew R. Cook, 'Counter-narratives of slavery in the Deep South: the politics of empathy along and beyond River Road,' Journal of Heritage Tourism, Vol. 11, No. 3 (2016): 290-308, 296.

${ }^{48}$ Ciji Dodds, Danielle Fuentes Morgan, and Lauren B. Parker, 'Drink it Up,' Black Girl Magic, podcast audio, May 11, 2016, https://soundcloud.com/blackgirlmagicpod/drink-it-up.
} 
vocal solo. The arrangement has a distinctly muted quality that invites the perceptive listener to distinguish the subtle sonic nuances in the performance as a whole; indeed, while Knowles Carter's voice is clear and mellifluous, we can also discern the quiet and constant hum of cicadas in the background. This separate layer of sound has uncontested roots in the cultural landscape of the American South, which is borne out by the pervasive presence of live oaks which surround the stage. These multi-sensory allusions to nature create a geographical anchor for Knowles Carter's performance which is reminiscent of the natural aesthetics of Lorraine Gendron's woodcut sculpture. In other words, we are made to feel a palpable symbiosis between place, performance, and Afro-Creole culture.

This multimedia engagement with place recognizes the fundamental importance of AfroCreole culture in the evolution of Black American musical forms, from jazz through rock and roll, soul, RnB, and hip hop. Throughout the age of slavery, but especially during the French and Spanish colonial period, New Orleans, in particular, became a locus of rhythmic activity for Creoles of colour from across the Atlantic. The emergent confluence of performance cultures was compounded by the Saint-Domingan diaspora and the large population of Saint-Domingan slaves that were forced to adapt to a new colonial environment through various performative and expressive modes. ${ }^{49}$ These performative modes ultimately found their expression in 'Congo Square', a public square in the Faubourg Trémé which served, under the French, Spanish, and even American administrations, as a marketplace for Creoles of colour, enslaved and free. This marketplace afforded its purveyors the opportunity to gather together and exchange and trade material goods, but also to dance, sing, and pay homage to their shared African routes. As Shirley Thompson notes, Congo Square had a 'long-standing significance in the cultural and racial geography of New Orleans,' and 'exemplified the process of creolization' ${ }^{50}$ The dances and songs of Congo Square bore the ancestral hallmarks of diverse West and Central African performance cultures, but also gave collective voice to the struggles and strife of New World existence for people of African descent more broadly. As Martin Munro notes, 'ceremonial dances $[\ldots]$ fostered a sense of community and identity among the diverse ethnic African groups

\footnotetext{
${ }^{49}$ Martin Munro, Different Drummers: Rhythm and Race in the Americas (Berkeley, Los Angeles and London: University of California Press, 2010), 42.

50 Shirley Elizabeth Thompson, Exiles at Home: The Struggle to Become American in Creole New Orleans (Cambridge and London: Harvard University Press, 2009), 106.
} 
and between them and the Creole slaves [...] born in the New World ${ }^{, 51}$ By galvanizing a variety of performative media within this locale, they created what Gilroy might call a 'lower frequency' rebel language that was passed from one generation to the next - a language that has informed the Africanization of Creole New Orleans. ${ }^{52}$ The syncretic transformation of African performance cultures within the cultural nexus of Creole Louisiana was thus peculiar to its locality. As Woods suggests of blues geography, the roots (and routes) of Creole Louisiana can be better understood through an Afro-Creole poetics because it reminds us of the need to interrogate its intersections and borders. ${ }^{53}$ The symbolic links between expressive form and natural environment in Knowles Carter's video are therefore by no means accidental, but rooted in a complex regional narrative that speaks directly to modes of performative countercultural resistance.

The process of exchange and transformation that was so central to the creolization of performance culture in Louisiana is replicated in the transition from vocal solo into a tutti. The use of percussive sounds created by snare, cymbals, and bass, supporting a melody that draws heavily on the jazz organ, anchors this performance firmly within the jazz idiom. By invoking these expressive modes, Knowles Carter underscores the powerful legacies left by African communities on the Creole landscape and demonstrates how performative languages of resistance have rippled out from lower-frequency epicentres across a global trajectory. By immersing ourselves in these sights and sounds, and teasing out the nuances between performative modes, we are forced to engage in a cultural, historical, and geographical excavation of Afro-Creole life at Destrehan which provide a a fuller understanding of its transgenerational and transnational intersections. Although Destrehan's tour guides endeavour to elicit a similar kind of cultural understanding through 'show and tell' demonstrations, Knowles Carter bridges the affective distance that these activities evoke through immersive, contextualized multimedia content that showcases the reaches of human agency and the symbolic interrelationship between landscape and culture in Afro-Creole communities.

\footnotetext{
${ }^{51}$ Munro, Different Drummers, 28.

${ }^{52}$ Gilroy, The Black Atlantic, 37.

${ }^{53}$ Woods, 66.
} 
The celebration of jazz is nevertheless offset through symbolic allusions to European classicism. The torches that light the stage, for example, recall the sacred flame of Vesta. This allusion is amplified by the vigil of female spectators. ${ }^{54}$ This classical symbolism is also reflected in accessories worn by members of Knowles Carter's female entourage. During the instrumental interlude, the Sierra Leonean ballet dancer Michaela De Prince takes to the stage crowned in a laurel wreath, for example, harnessing the symbolism of Greek mythology (Figure 12) ${ }^{55}$ Later in the sequence, the model Winnie Harlow is shown wearing a crown of thorns - a distinct allusion to Christ and the Passion. The concatenation of classical and biblical images in this sequence subverts conventional correlations between white, slaveholding culture and classicism (seen in the Palladian aesthetics of plantation infrastructures), and demonstrates how such cultural aesthetics were also embedded in and re-articulated by Afro-Creole communities. The Catholic tradition of Mardi Gras and its transmutations in the New World provide a fitting example of the ways in which European ideas, festivities, and belief-systems were re-articulated by Afro-Creole communities in the age of slavery. In Lemonade's 'Hope' sequence, the spirit of Mardi Gras is manifested in the form of a Mardi Gras Indian. As a popular festival in the Roman Catholic calendar, Mardi Gras travelled to the Americas with the European settlers, and became embedded in the cultural life of Latin-language colonies. As Reid Mitchell notes, however, it offered those from Afro-Creole communities a 'space in which to develop traditions that originated in Africa, as well as a chance to defy racial conventions. ${ }^{56}$ In this setting, Black processions took place under the guise of the masquerade traditions that sprang from Renaissance Europe. Although there are few written examples of the ways in which free and enslaved people of colour navigated these traditions in Creole Louisiana, an edict issued by the colonial government in 1781 decreed that 'all kinds of masking and public dancing by the Negroes be prohibited during the Carnival Season', which reflects a pervasive colonial anxiety about the re-appropriation of European festivities by Creoles of colour. ${ }^{57}$ As Aching suggests, Mardi Gras gave rise to 'instances of lower-frequency politics' that Afro-Creole Louisianians used to 'gain and maintain visible representation within the region's democracies'. Knowles

\footnotetext{
${ }^{54}$ Mike Dixon-Kennedy, Encyclopedia of Greco-Roman Mythology (Oxford: ABC-CLIO, 1998), 318.

55 Victoria Sherrow, Encyclopedia of Hair: A Cultural History (Westport and London: Greenwood Press, 2006$), 4$.

${ }^{56}$ Reid Mitchell, All on a Mardi Gras Day: Episodes in the History of New Orleans Carnival (Cambridge and London: Harvard University Press, 1995), 37.

57 'Chronological Digest of the Acts and Deliberations of the Cabildo-1781,' City Archives (New Orleans Public Library, 2002), accessed 30 September 2015, http://nutrias.org/ nopl/inv/digest/digest1781.htm.
} 
Carter's invocation of classical and biblical aesthetics, coupled with her specific allusions to the Mardi Gras traditions of New Orleans, therefore speak directly to the tradition of syncretic rearticulation of European forms by Afro-Creole communities in Louisiana. It also speaks to the forms of cultural resistance enacted within the very structures of power that historically sought to delimit and subjugate such communities. In this way, Knowles Carter explodes our understandings of Afro-Creole resistance — understood at Destrehan largely through the prism of particular historical events - and grounds it in the everyday experience of Afro-Creole life, thereby demonstrating the continuous revolutionary potential of the Creole plantation.

Though speaking, in part, to a need for liberation from oppressive relationships, and from the feelings of invalidation and shame that they often elicit, the lyrics to 'Freedom' invariably chime with this idea. In the context of the plantation setting, these lyrics resonate with historical struggles against oppressive plantation infrastructures and their legacies. These struggles are represented not by a singular moment of collective action, but by the multifarious actions of individuals. In the chorus, for example, Knowles Carter issues the repeated declaration:
I break chains all by myself,
Won't let my freedom rot in hell.
Hey! I'ma keep running
Cause a winner don't quit on themselves. ${ }^{58}$

Here, the pervasive use of personal pronouns reinforces individual pathways to resistance against systems of repression. The potential slippage in meaning (if we consider, for example, that the lyrics also speak to resistance against emotionally abusive relationships) also resonates with the powerful ways in which Afro-Creole communities codified their own emancipatory struggles through language. This was often borne out in the context of the Creole plantation through folktales, work songs, and spirituals. ${ }^{59}$ Certainly, the rhetoric of freedom was by no means lost on Black people in the slave-owning Americas, and it had a peculiar resonance for the people of African descent in the lower Mississippi Valley given the seismic impact of the Saint-Domingan diaspora and attendant murmurings about the insurgent influence of 'French negroes' in the

\footnotetext{
58 Beyoncé and Kendrick Lamar, 'Freedom', Lemonade (Parkwood Entertainment: 2016), https://listen.tidal.com/album/59727856.
} 
region. Local authorities had particular cause for concern about the 'contagious' spread of such rebellious rhetoric after the German Coast rebellion of 1811. Writing in the wake of the uprising, Peter Regnier, assistant to the Secretary of the Territory of Orleans, wrote that he had charged a number of Mississippi ferrymen to observe any 'foreign' arrivals - especially people of colourwith caution. ${ }^{60}$ As a result of such heightened surveillance, people of colour had to exercize extreme caution when talking about freedom. However, while insurgent discourses were often forced to mediate 'lower frequencies', they had a profound and far-reaching impact on AfroCreole communities. In Lemonade's 'Hope' sequence, proclamations of freedom are made in plain sight, on an elevated platform. Knowles Carter invites the specular gaze of her audience, and, in so doing, brings the insurgent and rebellious voices of her Afro-Creole ancestors to the foreground, creating a higher frequency that might facilitate their universal dissemination. Within the sequence, the process of 'symbolic excavation' is thus made the leading rationale for the plantation site as a whole, and is no longer consigned to a separate posterior space that viewers can opt not to see. In this way, each component —each site of memory—works in tandem to rehabilitate occluded voices and demonstrate the intersectionality of Creole cultures and the overlapping value systems of those cultures.

Lemonade's 'Hope' sequence therefore engages interdisciplinary approaches to help 'excavate' the historical possibilities of the Creole plantation that cannot be properly conceptualized or theorized within the limited parameters of the archives or through conventional modes of telling at docent-led historic sites. The trans-historical multimedia apparatus also broadens our understanding of how Afro-Creole life evolved on the plantation and offers evocative insights into the ways in which diasporic Black cultures informed, re-articulated, and eluded repressive white Creole infrastructures. In short, Knowles Carter forces us to consider the intersections and interdependencies of Creole life writ large within the scope of Destrehan Plantation, and presents a model for narrativizing plantation spaces more generally through

\footnotetext{
${ }^{59}$ Gilroy, The Black Atlantic, 168.

${ }^{60}$ They were asked 'd'observer les étrangers qui arriveront ici du Mississipi, particulièrement les gens de couleur, étant d'opinion que le massacre de la paroisse St. Jean n'auroit pas eu lieu, si les esclaves et gens libres émigrés de St. Yago n'eussent pas été admis dans las Louisiane.' Translation: 'to observe the foreigners who arrive here from the Mississippi, particularly people of colour, being of the opinion that the massacre in St. John [the Baptist Parish] would never have happened if the slaves and free people who had migrated from Santiago [de Cuba] had not been admitted to Louisiana.' Peter Regnier Letter, Mss. 364, Louisiana and Lower Mississippi Valley Collections, LSU Libraries, Baton Rouge, La.
} 
artistic practice. Lemonade reinforces the need for the plantation to engage in concerted acts of realignment to consciously redress its historical imbalances and bring its disruptive and affective memory-spaces to the foreground.

Of course, it cannot be ignored that 'Beyoncé', as popular cultural icon, is a wellestablished and highly lucrative commercial brand that partly problematizes this strategy of realignment. While Lemonade re-centres Afro-Creole histories that are so often 'annihilated' in the plantation narrative, it also re-commodifies those histories and the Black bodies at their locus. Lemonade is, after all, a commodity, and not a social enterprise. After it made its unannounced debut on $\mathrm{HBO}$, the premium satellite and cable television network (accessible to less than half of American households $)^{61}$ it was made available on both Amazon and iTunes as part of the full album download, limiting access to those with the purchasing power to download an entire musical album. It was also made exclusively available to subscribers of TIDAL, the music-streaming service owned by Knowles Carter's husband, Shawn 'Jay-Z' Carter. As such, it is difficult to extricate Lemonade's radical artistic vision from its function within the expansion of the Knowles-Carter empire. Certainly, the neoliberal philosophy of 'bootstraps' determination leading to earned wealth that Gilroy has shown to be so dominant within hip hop culture is partly bound up with Lemonade's central coda of Black (and specifically Black female) uplift. ${ }^{62}$ This message is especially compelling in the 'Anger'/'Don't Hurt Yourself' sequence where Knowles Carter shout-raps the words 'keep your money, I got my own', compounding a narrative of female financial autonomy and defiance. ${ }^{63}$ This narrative is reinforced through the visual prominence of sports apparel. As bell hooks highlights, Knowles Carter's use of 'sporty casual clothing' throughout Lemonade not only draws on and actively subverts racialized media representations of African American youth, but also serves as a subliminal marketing tool for the type of body-positive clothing that has inspired Knowles Carter's sportswear brand 'Ivy Park' ${ }^{64}$

\footnotetext{
${ }^{61}$ As of December 2016, HBO had an estimated 54 million subscribers in the United States. See 'Number of HBO subscribers worldwide from 2010 to 2017 (in millions)', Statista: The Statistics Portal, accessed 21 September 2018, https://www.statista.com/statistics/329277/number-hbo-subscribers/.

${ }^{62}$ Paul Gilroy, 'Race and Racism in "The Age of Obama"', The Tenth Annual Eccles Centre for American Studies Plenary Lecture Given at the British Association for American Studies Annual Conference (The British Library, 2013), 13-17.

${ }^{63}$ Beyoncé and Jack White, 'Don't Hurt Yourself', Lemonade (Parkwood Entertainment: 2016), https://listen.tidal.com/album/59727856.

${ }^{64}$ bell hooks, 'Moving Beyond Pain, The bell hooks Institute, May 9, 2016, http://www.bellhooksinstitute.com/blog/2016/5/9/moving-beyond-pain.
} 
In hooks's assessment, 'this is the business of capitalist money-making at its best' ${ }^{65}$ Once again, however, it is important to question how such conservative ethics of self-reliance speak to the lived realities of women of colour whose labour is often exploited for commercial gain in the production of such material goods. Such contradictions between the artistic agenda and the ethics of production inevitably constrain the powerful and regenerative force of Lemonade's rebellious Afro-Creole poetics and its ability to transcend Destrehan's elite white veneer.

Nonetheless, in challenging the ethics of Lemonade's production, it is important to recognize that Knowles Carter, as a woman of colour, is especially vulnerable to critique, and is often held to higher standards than wealthy white women who operate under the auspices of feminism. ${ }^{66}$ It is also important to recognize that, in shaping a new critical discourse that engages with creative, multimodal practice to excavate occluded Afro-Creole histories and built sustainable, community-oriented futures, artists undertake difficult and controversial work that is almost always incomplete and imperfect. As such, however, it offers a model that, by token of its imperfect nature, facilitates an interactive process of revision, renegotiation and reinvention that paves the way for radical new possibilities. In this sense, the kinds of counter-narratives proposed by the likes of Gendron and Knowles Carter should be seen as a starting point rather than an end point for the excavation of occluded Afro-Creole histories.

The imagined possibilities presented by these counter-narratives demonstrate the need to continue the work of radical overhaul on the Creole plantation. It is no longer adequate to 'integrate' occluded Black histories into the existing narrative framework of heritage tourism, as that framework remains fundamentally bound up with the oppressive apparatus of the plantation system. Afro-Creole histories should be used, in other words, to strategically shape new modes of narrativization and interpretation. Although Destrehan is making strides to effect these important changes, soliciting collaborations between regional scholars and artists to mark

\footnotetext{
65 hooks.

${ }^{66}$ Writing in response to hooks's acerbic critique of Lemonade, the Ebony columnist Jamilah Lemieux highlighted the contradiction between hooks's denigration of Knowles Carter and her support for the feminist campaign work of the actor Emma Watson. See Jamilah Lemieux, 'bell hooks and the Sour "Lemonade” Review, Ebony, May 11, 2016, https://www.ebony.com/news-views/bell-hooks-lemonade-beyonce.
} 
important events in Destrehan's history, ${ }^{67}$ this work needs to be ongoing, and not purely commemorative. If Creole histories continue to be narrativized in selectively affective ways, then they will only ever be understood through a historical framework that privileges momentary event-ness, decontextualized from evolving histories that inform the present moment. By contrast, multimedia modes of telling that draw on interdisciplinary interpretative approaches (enacted not just through scholarly activity, but through artistic and activist memory-work that explores a host of imagined possibilities) help us to understand the transgenerational legacies of enslavement and colonization and the diverse insurgent responses of Afro-Creole culture through to the present.

\footnotetext{
${ }^{67}$ In 2011, for example, a symposium was held to commemorate the bicentenary of the 1811 German Coast uprising that was hosted jointly by Tulane University and Destrehan Plantation entitled 'Black Resistance in an Age of Revolution: A Symposium Commemorating the Bicentennial of the 1811 Slave Uprising in Territorial Louisiana.'
} 